\title{
An unprecedented octahydro-3 Hoxeto[2,3,4-ij]isochromene ring system formed by a trichloromethyl-anion-induced reaction cascade
}

\author{
Witali Schmidta \\ Peter G. Jones ${ }^{b}$ \\ Jennifer Herrmannc \\ Rolf Müllerc
}

Stefan Schulz*a

a Institute of Organic Chemistry, Technische Universität Braunschweig, Hagenring 30, 38106 Braunschweig, Germany.

${ }^{b}$ Institute of Inorganic and Analytical Chemistry, Technische Universität Braunschweig, Hagenring 30, 38106 Braunschweig, Germany.

c Department Microbial Natural Products, Helmholtz Institute for Pharmaceutical Research Saarland, Helmholtz Centre for Infection Research, Saarland University, Campus E8.1, 66123 Saarbrücken, Germany.
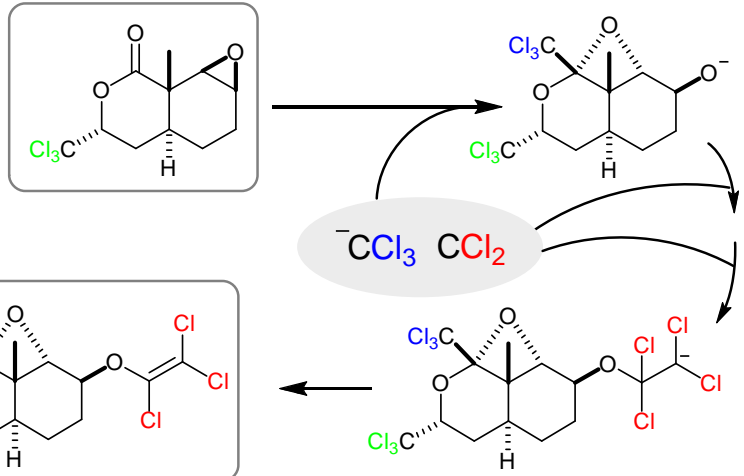

* indicates the main/corresponding author.

stefan.schulz@tu-bs.de

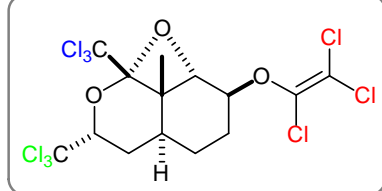
\section{(1)}


results were obtained with dimethyldioxirane (DMDO), ${ }^{3}$ resulting in an almost quantitative conversion leading to a 1:2 mixture of the two epoxides $\mathbf{8}$ and the major compound $\mathbf{9}$ separable by column chromatography. Because the trichloromethyl group tends to promote crystallization, X-ray crystallography allowed the assignment of the diastereomers (see SI).

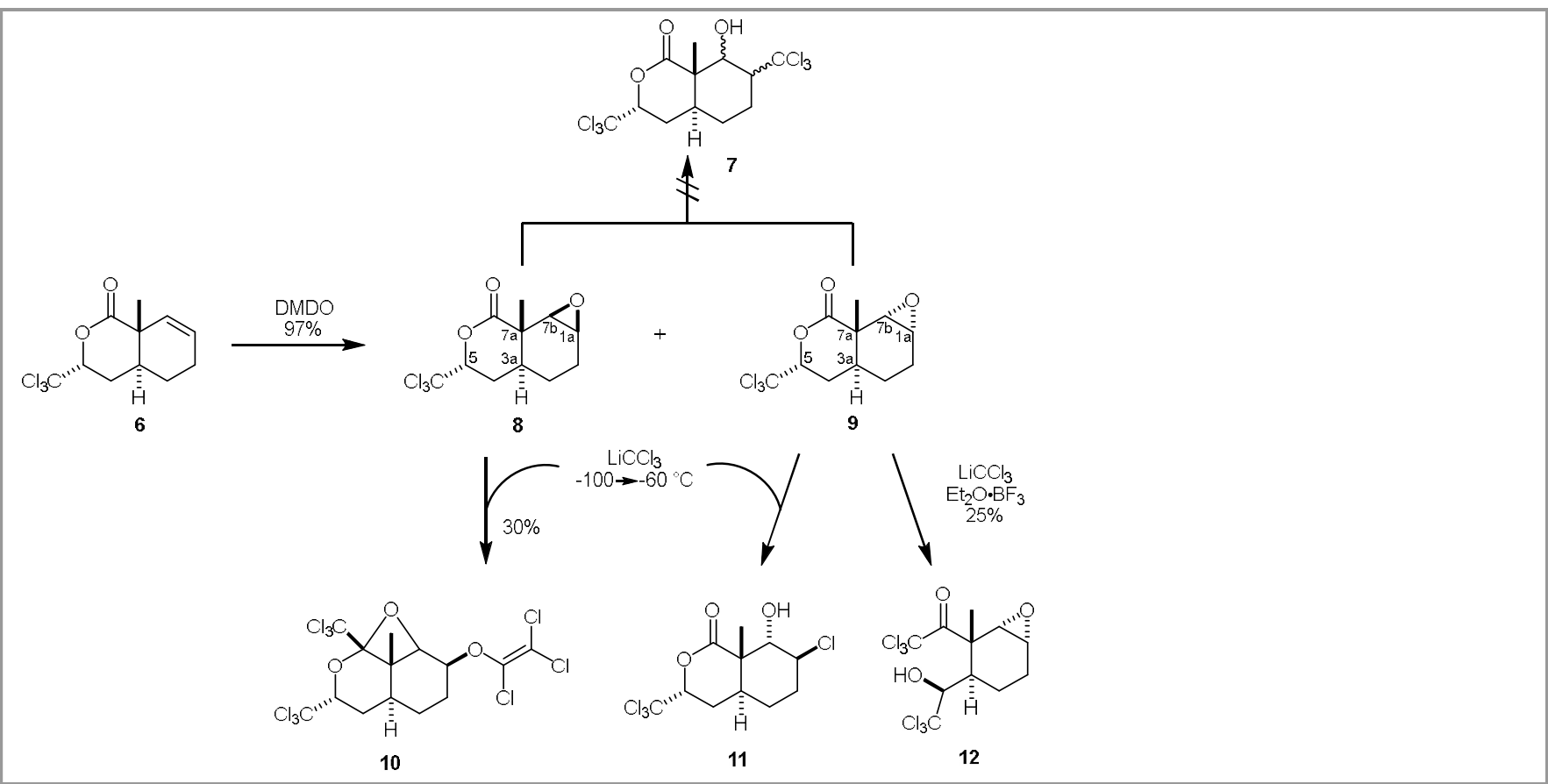

Scheme 2 Synthesis of epoxides 8 and 9 and reaction with trichloromethyl lithium.

Various methods were used for generation of the trichloromethyl anion. Trimethyl(trichloromethyl)silane and LiHMDS $^{4}$ proved to be insufficiently reactive, leading to unreacted starting material and minor amounts of side products. The reaction of trichloromethyl lithium, generated from chloroform and n-butyl lithium, in the presence of boron trifluoride etherate ${ }^{5}$ at $-95^{\circ} \mathrm{C}$ furnished the lactone-opened product 12, because the Lewis acid activated the ester group, but not the epoxide. Omission of the Lewis acid reduced activity, leading to no observable reaction. To increase reactivity, a large excess of the anion was used, accompanied by an increase of the reaction temperature to $-60^{\circ} \mathrm{C}$ after anion generation. Epoxideopened products were indeed observed, but the outcome was unexpected. Epoxide $\mathbf{9}$ was converted not into the desired product 4, but the chloride $\mathbf{1 1}$. Obviously, the relatively small chloride ion reacted instead of the trichloromethyl anion, for which axial attack is hindered by the quasi-axial bridgehead methyl group. Chloride attack occurred regioselectively on epoxide carbon $1 \mathrm{a}$ in agreement with the Fürst-Plattner rule, ${ }^{6}$ leading to a trans-diaxial halohydrine structure (Scheme 3).

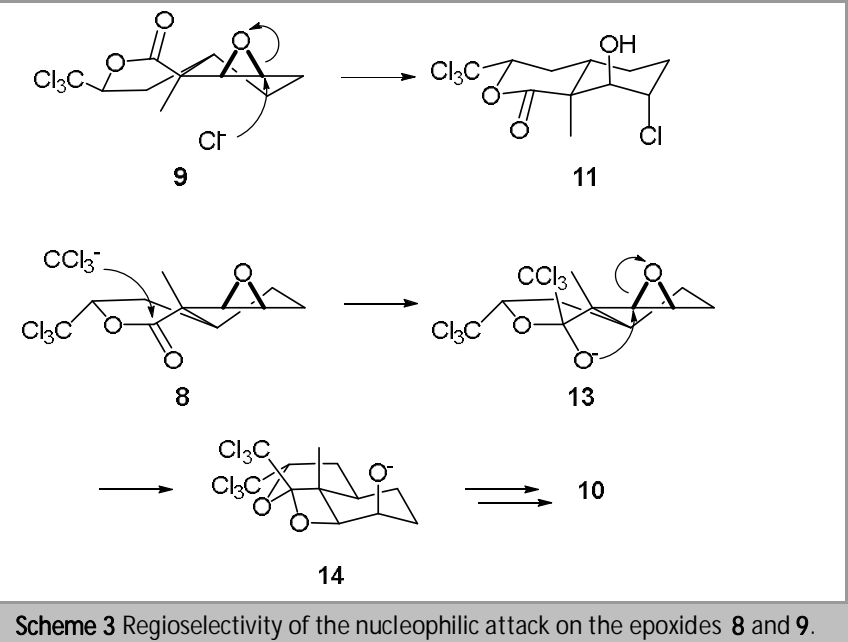

In the case of diastereomer $\mathbf{8}$, axial attack of the epoxide seems to be hindered by the ester and bulky trichloromethyl-groups. Instead of the desired product, the unexpected tricyclic compound 10 was formed.7 The structure, exhibiting an unusual oxetane, as part of an acetal, and nine chlorine atoms, was confirmed by X-ray crystallography (Figure 1). ${ }^{8}$ 


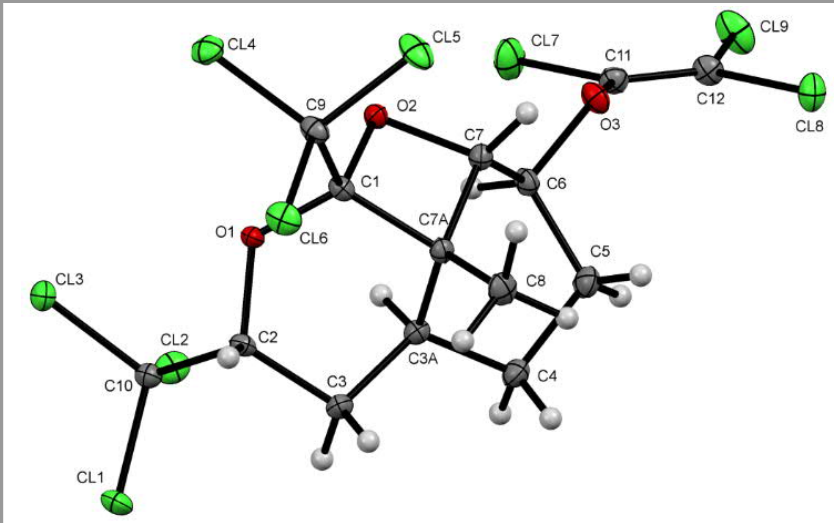

Figure 1 ORTEP diagram of X-ray analysis of octahydro-3 Hoxeto[2,3,4ij]lisochromene (10).

The formation of $\mathbf{1 0}$ can be explained by the involvement of both the trichloromethyl-anion and dichlorocarbene in the reaction (Scheme 4 ). Above $-70^{\circ} \mathrm{C}$, the trichloromethyl-anion exists in equilibrium with dichlorocarbene and $\mathrm{Cl}-.9$ In a cascade reaction the trichloromethyl-anion first attacks the carbonyl group of $\mathbf{8}$, bringing the oxygen-anion thus formed into close proximity with the epoxide. The epoxide is now opened, and the resulting alkoxy-anion $\mathbf{1 4}$ can react with dichlorocarbene. The new anion $\mathbf{1 5}$ cannot stabilize itself and reacts with a second dichlorocarbene to form the third anion 16, which loses chloride to form 10. A five step sequence is followed to arrive at the final product. Alternatively, a substitution of the alkoxide $\mathbf{1 4}$ at tetrachloroethene might also be possible, although not very probable because of the low concentration of this dichlorocarbene dimerization product in the reaction mixture. The presence of dichlorocarbene was also supported by small amounts of 2-dichloromethyltetrahydrofuran, tetrachloroethene, and 1,1-dichloro-2,3-dipropylcyclopropane in the reaction mixture, as detected by GC/ MS

According to the Fürst-Plattner rule, ${ }^{6}$ the epoxide is now regioselectively opened at $\mathrm{C}-7 \mathrm{~b}$ (Scheme 3 ). Direct attack of a nucleophile, e. g. $\mathrm{Cl}^{-}$or $\mathrm{CCl}_{3}$ - on the epoxide is hindered by the adjacent carbonyl group. Therefore, the nucleophile in this case attacks the carbonyl group from the least hindered side. Now the oxy-anion in $\mathbf{1 3}$ is properly positioned to attack C-7b, leading to the observed stereo- and regioselectivity of the reaction cascade.

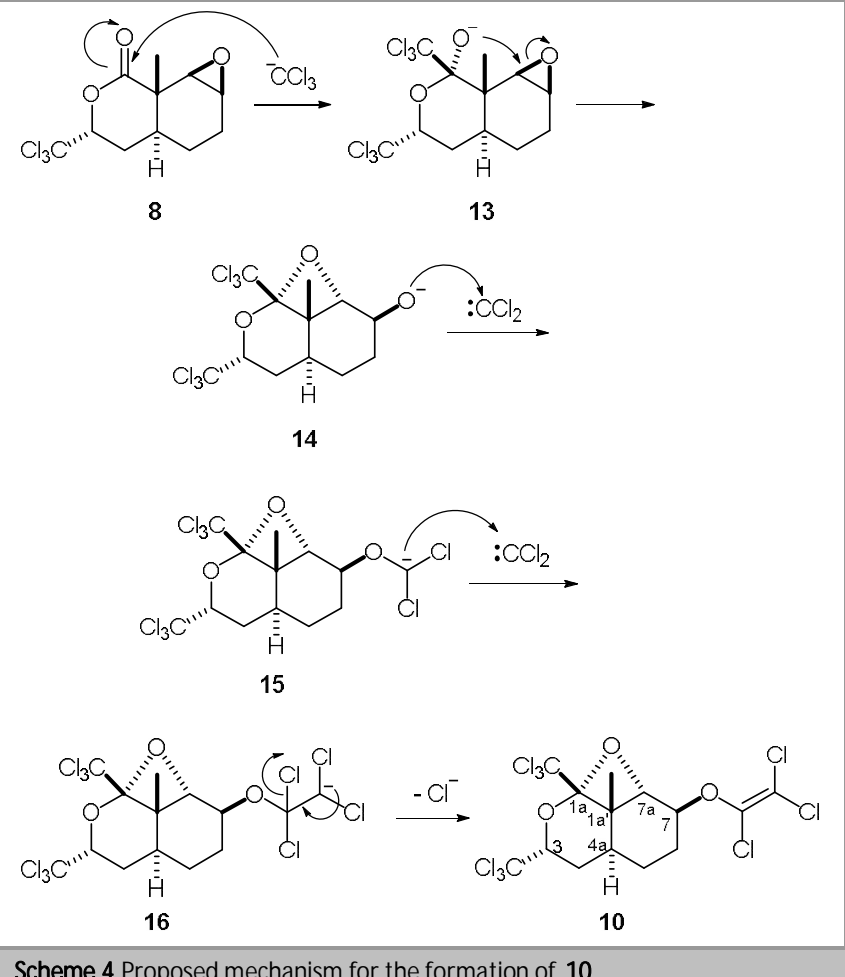

Scheme 4 Proposed mechanism for the formation of 10

Acetal $\mathbf{1 0}$ is stable and can be isolated by column chromatography. Obviously the large chlorine substituents shield the compound from attack and the acetal group itself is stabilized by the strongly electron-withdrawing trichloromethyl-groups. The almost planar oxetane ring and the trichloromethyl-substituents lead to a boat-like conformation of the two six-membered rings (Figure 1).

The tricyclic 3H-oxeto[2,3,4-ij]isochromene ring system has not been reported before. Even the simpler 2,8dioxabicyclo[4.2.0]octane system has only rarely been prepared, using photochemistry ${ }^{10}$ and cycloadditions. ${ }^{11}$ A nucleophilic displacement to form this type of acetal has not been reported before, to the best of our knowledge.

Sigillin A (1) is highly active as an insect-repellent. ${ }^{1}$ We were also interested whether $\mathbf{1}$ or the new compound $\mathbf{1 0}$ had other biological activities. Therefore, they were tested for antimicrobial and cytotoxic activity. Whereas no antimicrobial activity was observed, both compounds showed some cell toxicity, for $\mathbf{1 0}$ in the low $\mu \mathrm{mol}$ range (see SI). Although no antibacterial was observed until a concentration of $2 \mu \mathrm{M}$ with human pathogenic bacteria, it might be possible that $\mathbf{1}$ indeed protects the springtails against microorganisms, because its concentration in the springtail can reach $4 \mathrm{mM} .{ }^{1}$

In summary, although the original synthetic idea leading to sigillins was unsuccessful, a unique cascade reaction has been discovered, leading to a new, highly chlorinated tricyclic system.

\section{Acknowledgment}

Click here to insert acknowledgment text.

\section{Supporting Information}

YES (this text will be updated with links prior to publication) 


\section{Primary Data}

$\mathrm{NO}$ (this text will be deleted prior to publication)

\section{References and Notes}

(1) Schmidt, W.; Schulze, T. M.; Brasse, G.; Nagrodzka, E.; Maczka, M.; Zettel, J.; Jones, P. G.; Grunenberg, J.; Hilker, M.; Trauer-Kizilelma, U. et al., Angew. Chem. Int. Ed. 2015, 54, 7698-7702.

(2) Zettel, J.; Zettel, U., Mitt. Naturforsch. Ges. Bern 2008, 65, 79-110.

(3) Crandall, J. K.; Rambo, E., Tetrahedron 2002, 58, 70277036.

(4) Henegar, K. E.; Lira, R., J. Org. Chem. 2012, 77, 29993004.

(5) Imai, T.; Nishida, S.; Tsuji, T., J. Chem. Soc., Chem. Commun. 1994, 2353-2354.

(6) Fürst, A.; Plattner, P. A., Helv. Chim. Acta 1949, 32, 275283.

(7) Synthesis of 10: Abs. $\mathrm{CHCl}_{3}(0.478 \mathrm{~g}, 0.323 \mathrm{~mL}$, $4.00 \mathrm{mmol}$ ) was added to abs. THF (15 mL), cooled to $-98^{\circ} \mathrm{C}$ and finally $\mathrm{nBuLi}(2.50 \mathrm{~mL}, 1.6 \mathrm{~m}$ in hexane, $4.00 \mathrm{mmol}$ ) was added. After stirring for $15 \mathrm{~min}$, a solution of epoxide $\mathbf{8}$ ( $24 \mathrm{mg}, 0.08 \mathrm{mmol}$ ) in abs. THF $(1 \mathrm{~mL})$ was slowly added. The reaction mixture was allowed to warm up to $-60^{\circ} \mathrm{C}$ during $3 \mathrm{~h}$. After hydrolysis with sat. aq. $\mathrm{NH}_{4} \mathrm{Cl}$, the phases were separated and the water phase extracted three times with dichloromethane. The combined organic phases were dried with $\mathrm{MgSO}_{4}$, filtered, and the solvent was evaporated. The crude product was purified by flash chromatography on silica (pentane/ diethyl ether 10:1). The product was isolated as colorless crystals (13 mg, $0.024 \mathrm{mmol}, 30 \%) . \mathrm{R}_{\mathrm{f}}=0.61\left(\text { Pentane/ } \mathrm{Et}_{2} \mathrm{O} 2: 1\right)^{1} \mathrm{H}-\mathrm{NMR}$ $\left(400 \mathrm{MHz}, \mathrm{CDCl}_{3}, \mathrm{TMS}\right): \delta[\mathrm{ppm}]=5.00\left(\mathrm{~d}, 1 \mathrm{H}, \mathrm{H}-7 \mathrm{a},{ }^{3} \mathrm{~J}_{\mathrm{H}, \mathrm{H}}\right.$ $=3.8 \mathrm{~Hz}), 4.95\left(\mathrm{dd}, 1 \mathrm{H}, \mathrm{H}-3,{ }^{3} \mathrm{~J}_{\mathrm{H}, \mathrm{H}}=8.5 \mathrm{~Hz},{ }^{3} \mathrm{~J}_{\mathrm{H}, \mathrm{H}}=7.2 \mathrm{~Hz}\right)$, 4.76 (ddd, $1 \mathrm{H}, \mathrm{H}-7,{ }^{3} \mathrm{JH}_{\mathrm{H}, \mathrm{H}}=12.8 \mathrm{~Hz},{ }^{3} \mathrm{~J}, \mathrm{H}=4.4 \mathrm{~Hz},{ }^{3} \mathrm{JH}_{\mathrm{H}, \mathrm{H}}=$ $3.8 \mathrm{~Hz}$ ), 2.68 (dddd, $1 \mathrm{H}, \mathrm{H}-4 \mathrm{a},{ }^{3} \mathrm{JH}_{\mathrm{H}, \mathrm{H}}=13.4 \mathrm{~Hz},{ }^{3} \mathrm{~J}_{\mathrm{H}, \mathrm{H}}=$ $\left.11.1 \mathrm{~Hz}, 3 \mathrm{~J}_{\mathrm{H}, \mathrm{H}}=7.8 \mathrm{~Hz}, 3 \mathrm{~J}_{\mathrm{H}, \mathrm{H}}=5.8 \mathrm{~Hz}\right), 2.17-2.08(\mathrm{~m}, 1 \mathrm{H}$, H-6), $2.14-2.06(\mathrm{~m}, 1 \mathrm{H}, \mathrm{H}-4), 2.07-1.99(\mathrm{~m}, 1 \mathrm{H}, \mathrm{H}-5)$, $1.83\left(\mathrm{ddd}, 1 \mathrm{H}, \mathrm{H}-4,{ }^{2} \mathrm{JH}_{\mathrm{H}, \mathrm{H}}=13.6 \mathrm{~Hz},{ }^{3} \mathrm{~J}_{\mathrm{H}, \mathrm{H}}=13.0 \mathrm{~Hz},{ }^{3} \mathrm{~J}_{\mathrm{H}, \mathrm{H}}=\right.$ $8.6 \mathrm{~Hz}), 1.71$ - 1.64 (m, 1H, H-5), $1.69-1.60$ (m, 1H, H-6), $1.46\left(\mathrm{~s}, 3 \mathrm{H}, \mathrm{CH}_{3}\right) .{ }^{13} \mathrm{C}-\mathrm{NMR}\left(100 \mathrm{MHz}, \mathrm{CDCl}_{3}, \mathrm{TMS}\right): \delta$ [ppm] =139.99 (COCl), $109.36\left(\mathrm{CCl}_{2}\right), 108.71(\mathrm{C}-1 \mathrm{a})$, $100.44\left(1 \mathrm{a}-\mathrm{CCl}_{3}\right), 99.78\left(3-\mathrm{CCl}_{3}\right), 86.47$ (C-7a), 84.35 (C3), 82.14 (C-7), 44.73 (C-1a), 33.64 (C-4a), 26.36 (C-4), 22.88 (C-6), 21.15 (C-5), $10.20\left(\mathrm{CH}_{3}\right)$. HR-MS (ESI+): calc.: $566.7959[\mathrm{M}+\mathrm{Na}]^{+}$, found: 566.7960 .

(8) CCDC numbers: 8 CCDC 1504299; 9 CCDC 1504300; 10 CCDC 1504301; 11 CCDC 1504302

(9) Köbrich, G., Angew. Chem. Int. Ed. Engl. 1972, 11, 473485.

(10) (a) Griesbeck, A. G.; Stadtmueller, S., J. Am. Chem. Soc. 1990, 112, 1281-1283. (b) Adam, W.; Kliem, U.; Peters, E. M.; Peters, K.; Schnering, H. G. von, J. Prakt. Chem. 1988, 330, 391-405.

(11) (a) Karakhanov, E. A.; Lysenko, S. V.; Kovaleva, N. F.; Brezhnev, L. Y.; Glukhovtsev, V. G.; Karakhanov, R. A., Vestn. Mosk. Univ., Ser. 2: Khim. 1982, 23, 159-163. (b) Sugimura, H.; Osumi, K., Tetrahedron Lett. 1989, 30, 1571-1574. 